\title{
THE RELATIONSHIP OF DEATH, SIN, AND LAW IN 1 COR 15:56
}

\author{
by \\ H.W. HOLLANDER AND J. HOLLEMAN \\ Leiden
}

One of the most problematic verses in the epistles of Paul is perhaps 1 Cor 15:56. * This verse stands almost at the end of the long and well-known passage in Paul's first letter to the Corinthians dealing with the issue of the resurrection of believers at the end of time.

After two quotations of OT passages, introduced to describe the future destiny of death at the end of time (vv. 54-55), and before a doxology expressing gratitude to God for the victory over death through Jesus Christ (v. 57), the apostle makes a statement about the relation between death, sin, and law: 'The sting of death is $\sin$, and the power of sin is the law' (v. 56).

This verse has given rise to a variety of interpretations in the history of exegesis. The most radical solution with regard to the seeming dissonance of these words in the whole of Paul's argumentation is the assumption of a gloss or interpolation, either by the apostle himself at a later time or by a redactor or editor of (some of) the Pauline letters. The critical apparatus of Nestle-Aland ${ }^{26}$ refers to the Dutch scholar J.W. Straatman as the one who was the first to conjecture verse 56 to be an interpolation. In his book on the first letter of Paul to the Corinthians Straatman underlines on the one hand the Pauline character of the verse but stresses on the other hand its dissonance in the context, which does not deal with sin or law at all. Consequently, he argues that the verse is an interpolation, a dogmatic note, inserted by someone who knew the corpus paulinum quite well. ${ }^{1}$

* We wish to thank Dr. A.J. Malherbe who was so kind to read the manuscript and make many helpful suggestions with regard to content and style.

1 See J.W. Straatman, Kritische Studiën over den Ien Brief van Paulus aan de Korintiërs I-II (Groningen: Van Giffen, 1863-1865) II, 284. 
Many scholars agreed with his conjecture of a gloss, among whom Von Soden, Johannes Weiss, Bousset, and Moffatt. ${ }^{2}$ In the course of time, however, students of the New Testament have become more sceptical towards the results of the Konjekturalkritik of the nineteenth century. And nowadays there is an almost general agreement about the authenticity of verse $56 .^{3}$

But that does not mean that the problems with regard to this statement and its position in chapter fifteen have been solved. Quite the contrary. The verse remains a puzzler ${ }^{4}$ and can be classified among 'the things that are hard to understand' in Paul's letters (2 Pet $3: 16) .^{5}$ One problem is, for instance, the question of how the statement about death, sin, and law functions in the whole of Paul's argumentation in chapter fifteen. Interpreters usually leave this question open and confine themselves to the interpretation of the statement itself. They often refer to Paul's letters to the Galatians and the Romans, especially to Rom 5-8, where the triad death-sin-law recurs, and attempt to interpret 1 Cor 15:56 from what is said in those letters about the relation between death, $\sin$, and law.

This procedure is followed in almost all modern commentaries on 1 Corinthians ${ }^{6}$ and in a number of monographs on Paul's attitude towards the (Jewish) law. ${ }^{7}$ His attitude towards the Torah

2 See F.W. Horn, '1 Korinther 15,56 - ein exegetischer Stachel', ZNW 82 (1991) 88-105, esp. 89-90.

3 F.W. Horn himself is still in favour of the idea that verse 56 is a gloss, inserted by 'a pupil of Paul' (Stachel, 104-105).

- Or, in the words of U. Wilckens, 'Im dortigen Kontext ist dieser Satz in seiner gedrängten, sentenzhaften Kürze rätselhaft ...' ('Zur Entwicklung des Paulinischen Gesetzesverständnisses', NTS 28 [1982] 161).

5 So, e.g., M. Winger, By what law? The Meaning of Nókos in the Letters of Paul (Atlanta: Scholars, 1992) 1.

${ }^{6}$ So, e.g., H. Conzelmann, Der erste Brief an die Korinther (2d ed.; Göttingen: Vandenhoeck \& Ruprecht, 1981) 361-2; G.D. Fee, The First Epistle to the Corinthians (Grand Rapids: Eerdmans, 1987) 805-7; H. Lietzmann, An die Korinther I-II (Tübingen: Mohr, 1969) 88; A. Robertson-A. PJummer, A Critical and Exegetical Commentary on the First Epistle of St Paul to the Corinthians (Edinburgh: Clark, 1911) 378-9.

7 For some recent studies on Paul's attitude to the law, see, e.5., A. van Dülmen, Die Theologie des Gesetzes bei Paulus (SBM 5; Stuttgart: Katholisches Bibelwerk, 1968); J.D.G. Dunn, Jesus, Paul and the Law (Louisville: Westminster/John Knox, 1990); H. Hübner, Das Gesetz bei Paulus. Ein Beitrag zum Werden der paulinischen Theologie (FRLANT 119; 2d ed.; Göttingen: Vandenhoeck \& Ruprecht, 1980); B.L. Martin, Christ and the Law in Paul (Suppl. NT 62; Leiden/New York/København/Köln: Brill, 1989); H. Räisănen, Paul and the Law (WUNT 29; Tübingen: Mohr, 1983); E.P. Sanders, Paul, the Law and the Jewish 
is generally regarded as the clue to his understanding of the relation between death, sin, and law. Even when exegetes bring the context of 1 Corinthians explicitly into the discussion, ${ }^{8}$ they seemingly cannot interpret 1 Cor 15:56 without referring to other Pauline letters. Their conclusion seems inevitable: as early as 1 Corinthians Paul's attitude towards the law was two-sided. Besides a positive assessment of the law, the apostle was fully aware of other aspects of the law, viz. those which were obsolete and poor, which belonged to the old order and the sphere of death and sin. ${ }^{9}$ Consequently, Paul's statement about death, sin, and law in 1 Cor 15:56 looks like 'a brief compendium of his own theology as to the relationship of sin and the law to death', ${ }^{10}$ which he, in a more polemical situation when Judaizing had become a problem, had to work out in more detail.

Though this interpretation of 1 Cor 15:56 may seem attractive, it is not without problems. The position and function of this brief statement on the connection between death, $\sin$, and law in the context of chapter fifteen is not yet explained. Why did Paul insert these words in an argument on the resurrection of believers in which sin has hardly figured and law not at all? And if we need other Pauline letters to explain the statement on death, sin, and law in 1 Corinthians, may we expect the Corinthians to have understood these words without any further comment? Or must we conclude that the communication between Paul and his addressees might have failed in this respect? And, even more important, does 1 Cor 15:56 really show an aspect of Paul's attitude towards the Jewish law, an issue so prominent in his polemics against Judaizing Christians, but which seems totally absent in the Corinthian situation? As far as we know, all interpreters of this verse start from the

People (Philadelphia: Fortress, 1983); P.J. Tomson, Paul and the Jewish Law. Halakha in the letters of the apostle to the Gentiles (Assen/Maastricht/Minneapolis: Van Gorcum/Fortress, 1990); U. Wilckens, Entwicklung; M. Winger, Law.

8 Like, e.g., Th. Söding, " Die Kraft der Sünde ist das Gesetz"' (1 Kor 15,56). Anmerkungen zum Hintergrund und zur Pointe einer gesetzeskritischen Sentenz des Apostels Paulus', ZNW 83 (1992) 74-84; and F. Thielman, 'The coherence of Paul's view of the law: the evidence of First Corinthians', NTS 38 (1992) 235-53.

9 On the tension between Paul's positive and negative statements about the law, see esp. H. Räisänen, Law, 140-54; B.L. Martin, Law, 19-20; 37-68; F. Thielman, Law, passim.

10 G.D. Fee, Corinthians, 805 . 
interpretation of vónos as the Torah, the Jewish law. But is this interpretation correct?

In the following, we will make a new attempt to analyse Paul's statement on the connection between death, sin, and law in 1 Cor 15:56 and to understand it in the context of Paul's communication with the Christian believers in the community of Corinth and not primarily from what is said in other Pauline letters. We will argue that both the connection between death and sin and the connection between sin and law are to be understood against the background of Hellenistic popular philosophy. Paul uses Hellenistic concepts current in popular philosophy to describe the deplorable state of humanity as one which is governed by death, sin, and law. He does so in order to contrast the present state of humanity with the eternal glory which will not to be received by the believers until Christ's parousia.

\section{The role of death in the context of 1 Cor 15:56}

In the fifteenth chapter of 1 Corinthians the apostle Paul discusses the resurrection of believers at the parousia of Christ. As an important item in his argumentation he stresses a few times the role of death in the life of mankind. He calls it 'the last enemy to be destroyed' at Christ's parousia (v. 26). Just before verse 56 the apostle returns to the issue of death. In verses 54-55 he refers to the end of time when death will be 'swallowed up in victory' (v. 54), a paraphrase of Isa 25:8, which he combines with another quotation from the OT, viz. Hos 13:14, 'Death, where is your victory? Death, where is your sting?'

Both citations vary from LXX (and MT), in vocabulary as well as-partly-in function. The passage of Isa 25:8 seems to be the key verse. Its function in 1 Cor 15 is in line with the OT context, where it is proclaimed that God will conquer death on the day of salvation. Paul introduces, or takes over, ${ }^{11}$ the formula eis vixos, not used in Isa 25:8 LXX, but a more or less common LXX idiom for

11 On a possible Vorlage of Paul's quotation, see D. A. Koch, Die Schrift als Zeuge des Evangeliums. Untersuchungen zur Verwendung und zum Verständnis der Schrift bei Paulus (Tübingen: Mohr, 1986) 60-63; Chr. D. Stanley, Paul and the language of Scripture. Citation technique in the Pauline Epistles and contemparary literature (Cambridge: University Press, 1992) 209-211. See further F.W. Horn, Stachel, 97-99; F. Thielman, Coherence, 248. 
the translation of the Hebrew לנצח, 'for ever', which is found in Isa 25:8 MT. By taking eis vixos literally, meaning 'to victory', he can interpret 'the victory over death through Jesus Christ' (v. 57) as the fulfillment of Isaiah's proclamation in Isa 25:8.

Next, Paul introduces a second OT passage, viz. Hos 13:14, which he-over against MT but perhaps in line with LXXunderstood as another reference to the future destiny of death. $\mathrm{He}$ obviously saw in the two phrases both beginning with the interrogative adverb $\pi$ ou rhetorical questions, meant to ridicule death and to show that the end of its power has come. ${ }^{12}$ The most important differences from LXX (and MT) are the double vocative

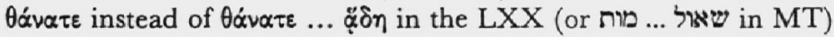
and the introduction of tò vixos for the LXX word $\delta$ ix $\eta$ (or Tבר in MT). Through these changes, which seem Pauline adaptations of the OT text, ${ }^{13}$ the Hosea text is brought to a high degree into verbal agreement with the Isaiah quotation. Both OT texts are now supplementary and strengthen each other in their function of showing the end of the power of death.

In spite of the victory over death 'through our Lord Jesus Christ' (v. 57), in spite of the fact that at the end of time, at Christ's parousia, death will definitely be destroyed as 'the last enemy' ( $\mathrm{v}$. 26), Paul emphasizes that death still is an active power in the life of mankind. For man still is perishable, mortal. In this context, Paul introduces the Adam-Christ analogy, for the first time in his surviving letters: as Adam stood at the beginning of the old order, Jesus Christ stands at the beginning of a new one. Consequently, 'since death came through a human being', viz. the first man, Adam, 'the resurrection of the dead has also come through a human being' (v. 21; NRSV). Or, in the words of verse 22, 'for as all die in Adam, so all will be made alive in Christ' (NRSV). Further on, in verses 45-49, Paul refers to the physical, earthly character of man conforming to the first man Adam over against the image of the spiritual man of heaven which the believers will

12 On the rhetorical use of $\pi \circ \tilde{v}$, see further, e.g., 1 Cor $1: 20$; Rom $3: 27 ; \mathrm{Gal}$ $4: 15$; Ps $42: 4,11$; Isa $19: 12 ; 33: 18 ; 36: 19 ; 37: 13 ; 51: 13 ; 63: 11,15$; Jer $2: 28$; in (Jewish) Hellenistic literature, Sib Or 5:67; 8:43-45, 79; Epictetus, Dissertationes III, 10, 17; Plutarch, Consolatio ad Apollonium 15 (Mor. 110 D); Marcus Aurelius X, 31; XII, 27, etc. See also K. Berger, Exegese des Neuen Testaments (2d ed.; Heidelberg: Quelle Meyer, 1984) 48.

13 See Chr. D. Stanley, Paul, 211-215. 
bear in the future. All men have shared the existence of the first Adam, the believers, however, will receive a heavenly body, spiritual and imperishable, at the end of time, due to their relationship with the risen Jesus Christ. ${ }^{14}$

By presenting mortality as something going back to the first man Adam, Paul shows familiarity with Jewish traditions. ${ }^{15}$ Jewish apocalyptic authors, for instance, like those of 4 Ezra and 2 Baruch, attributed death to the transgression of Adam, who broke God's command not to eat of the tree of the knowledge of good and evil (Gen $2: 17 ; 3: 1-24)$. Thus, Adam was regarded as the one by whose transgression physical death and an age of disaster and pain was brought to mankind ( 4 Ezra 3:7, 'And you laid upon him one commandment of yours; but he transgressed it, and immediately you appointed death for him and for his descendants ...' $;^{16} 2$ Bar 17:23 , 'For what did it profit Adam that he lived nine hundred and thirty years and transgressed that which he was commanded? Therefore, the multitude of time that he lived did not profit him, but it brought death and cut off the years of those who were born from him'17).

It was not only apocalyptic authors who found the explanation for the origin of death in Adam's transgression; other Jewish writers, like Philo, also did so. Philo's description of the first man reflects above all Greek philosophical concepts. According to him, Adam lived as a human being on the borderline of two worlds. While his body and sense-perception were shared with the animals, by virtue of his reason, his rational soul or mind, he could contemplate the heavens. At the very first beginning Adam was a

14 On the Adam-Christ analogy, see in particular E. Brandenburger, Adam und Christus. Exegetisch-religionsgeschichtliche Untersuchung zu Röm. 5,12-21 (1. Kor. 15) (Neukirchen: Neukirchener, 1962); A.J.M. Wedderburn, Adam and Christ (Cambridge 1970 [unpublished dissertation]); H.-H. Schade, Apokalyptische Christologie bei Paulus (2d ed.; Göttingen: Vandenhoeck \& Ruprecht, 1984) 69-87; and the literature mentioned in the Commentaries, ad 1 Cor 15:21-22, 45-49. On the future victory over death, see also M.C. de Boer, The Defeat of Death. Apocalyptic Eschatology in 1 Corinthians 15 and Romans 5 (JSNT Suppl. 22; Sheffield: JSOT, 1988).

15 See esp. E. Brandenburger, Adam, 15-64; J.R. Levison, Portraits of Adam in Early Judaism. From Sirach to 2 Baruch (JSP Suppl. 1; Sheffield: JSOT, 1988), and the literature mentioned in this monograph.

16 Trans. B.M. Metzger in J. Charlesworth (ed.), Old Testament Pseudepigrapha (OTP).

${ }_{17}$ Trans. A.F.J. Klijn in OTP. 
world citizen, living according to nature, which was the ideal of Cynicism and Stoicism. The first man was certainly more excellent in body and soul than all his descendants. But after the creation of woman the nature of the first man changed considerably. Mutual desire and bodily pleasure made man and woman sin, '... pleasure which is the beginning of wrongs and violation of law, the pleasure for the sake of which men bring on themselves the life of mortality and wretchedness in lieu of that of immortality and bliss

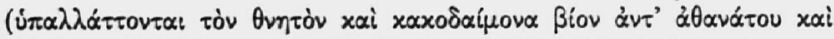

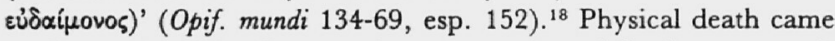
as the result of the first man's transgression of God's commands (Quaest. in Gen. 1, 51). All this implies that the traditional Jewish concept of Adam's transgression of God's command as the origin of mortality was employed by Paul in his argumentation on the future resurrection of believers and the power of death in the present situation of mankind. In Paul's view, death will remain a mighty power to which all mankind is subjected until the end of time.

Paul stresses the power of death in the present age, because his Corinthian addressees seemed to neglect it in their enthousiastic experiences of the gifts of the Holy Spirit. They felt wise, free, superior, and powerful, ${ }^{19}$ and they taunted death as something irrelevant. Such behaviour was common in Stoic and Cynic circles, ${ }^{20}$ and their slogans and ideas were obviously attractive to the Corinthians. In 1 Cor 15:54-55, Paul, too, derides death, but underlines that the triumph over death will be achieved not until the parousia. For the time being, death is still a power to be taken quite seriously.

18 Trans. F.H. Colson-G.H. Whitaker in Loeb Classical Library (LCL).

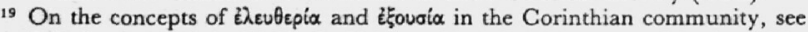
esp. F.S. Jones, Freiheit, 27-69; S. Vollenweider, Freiheit als neue Schöpfung. Eine Untersuchung zur Eleutheria bei Paulus und in seiner Umwelt (Göttingen: Vandenhoeck \& Ruprecht, 1989) 199-246; A.J. Malherbe, 'Determinism and Free Will in Paul: The Argument of 1 Corinthians 8 and 9', to appear in a volume edited by Troels Engberg-Pedersen and dedicated to the subject of Paul's Hellenistic milieu (Minneapolis: Fortress).

${ }^{20}$ Cynics and Stoics despised death and taunted it. Feeling free, they did not fear death. See J. Dalfen, Formgeschichtliche Untersuchungen zu den Selbstbetrachtungen Marc Aurels (Diss. München, 1967) 175-203; H. Niehues-Pröbsting, Der Kynismus des Diogenes und der Begriff des Zynismus (München: Wilhelm Fink, 1979) 140-9; S. Vollenweider, Freiheit, 72-74. 


\section{The relationship between death and sin in 1 Cor $15: 56$}

At the end of 1 Cor 15, Paul goes into the subject of death and the present age. Quoting Hos 13:14 in addition to the Isa 25:8 phrase, he could add a few more words about the connection between the power of death and man. Through Hos 13:14 Paul introduces the notion of 'the sting ( ting death as a scorpion or some kind of insect, able to 'sting' ${ }^{21}$ In the context, and applied to the connection between death and man, it means that death 'stings' men, making them perishable, mortal. Death injects mortality in man, and the means by which it does so is $\sin$. This is what verse 56 a means.

The mentioning of 'the sting of death' in Hos 13:14 enabled Paul to speak about the way in which death has the whole human race in its power. In his view, the 'sting' through which death brings mortality to all men, is 'sin', $\dot{\eta} \alpha \mu \alpha p \tau i \alpha .{ }^{22}$ According to Paul, there is a clear connection between death and sin, between the power of death and the power of $\sin ,{ }^{23}$ both being active in the life of mankind.

This connection was not Paul's own invention. Again, he took over a Jewish Hellenistic concept. As argued above, in many early Jewish writings we find the notion that Adam's transgression was the origin of mortality. But that did not necessarily imply that through Adam's transgression of God's law sin too appeared as a power in the present age. Death was transmitted to the human race, but $\sin$ was not. Of course, Jewish authors were aware of the fact that many of Adam's descendants sinned. Especially in apocalyptic writings the present time was regarded as an age of evil in which sin was omnipresent. On the other hand, however, they did not consider sin something absolutely unavoidable. Adam was a paradigm of man's possibility to choose: all men have free will and are able to choose, and are responsible for their own deeds. The law of God, the Torah, is given to them in order to make the right choice. Each one determines his (or her) destiny, whether salvation

21 On the use of xévipov, see the Commentaries, ad locum, and F.W. Horn, Stachel, 94 n. 16.

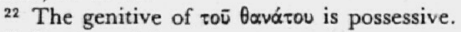

${ }^{23}$ Death and $\sin$ are represented here as some kind of powers. Cf. E. Brandenburger, Adam, 158-68 (on Rom 5:12). 
or damnation. The notion of hereditary sinfulness was strange to these Jewish authors. ${ }^{24}$

Philo, however, explicitly connects the Jewish concept of Adam's transgression as the origin of mortality to the present state of sinfulness of all mankind. As said before, Philo depicts the first man Adam as 'the bloom of our entire race' (Opif. mundi 140), more excellent in body and soul than all his descendants and living as a world citizen, acting according to the law of nature. After the 'fall' man's life of 'immortality and bliss' was changed into one of 'mortality and wretchedness' (Opif. mundi 152). Philo employs here the Greek philosophical concept of gradual degeneration, i.e. the notion that after the golden age of the beginning humanity degenerated to the present deplorable state, ${ }^{25}$ and he applies this concept to Adam and his descendants. Adam's descendants are inferior to the first man, Adam, who 'surpassed all the men that now are, and all that have been before us' (Opif. mundi 140). And 'as generation follows generation, the powers and qualities of body and soul which men receive are feebler' (Opif. mundi 141; cf. 148). ${ }^{26}$ Far from being world citizens living in harmony with nature, men have preserved only faint marks of the first man. Men's souls 'are filled with many sins' over against the souls of the first creatures, which were 'pure of evil' (Quaest. in Gen. 1, 32). When Adam and Eve transgressed God's command, 'they needed that which is made by hand and corruptible' in order to cover their nakedness; for their knowledge of being naked was 'opinion and the beginning of evil', which introduced 'a strangeness ... conceived by the mind toward the whole world' (Quaest. in Gen. 1, 40). ${ }^{27}$

Most probably, it was this Greek concept of degeneration linked up with the Jewish notion of mortality and an age of evil and pain as a consequence of Adam's transgression, as found in a Jewish Hellenistic author like Philo, that was used by Paul to describe the connection between death and sin, as he does in 1 Cor 15:56. ${ }^{28}$ After Adam's transgression of God's command, his violation of the law of God, mankind is characterized by mortality and sinfulness.

${ }^{24}$ Cf. esp. E. Brandenburger, Adam, 15-45; 165; J.R. Levison, Portraits, passim.

${ }^{25}$ See also section $3 \mathrm{~B}$ below.

26 Trans. F.H. Colson-G.H. Whitaker in LCL.

27 Trans. R. Marcus in LCL.

${ }^{28}$ In Romans, Paul will return to this theme, see Rom 5:12-21. 
Whether Paul thinks of a gradual degeneration or a sudden change to an age of wretchedness is not clear. In any case, in Paul's view, the Urzeit has passed, the age of the powers of death and sin has come, and it is not until the parousia of Jesus Christ that death will once and for all be overcome. By connecting death with sin Paul emphasizes the fallen nature of mankind from which Christians will be saved through resurrection at the end of time. The victory over death and the absence of sin at the end of time, are contrasted with the everyday reality of the Corinthians.

\section{The relationship between sin and law}

Paul goes even further in his depiction of the deplorable state of humanity: law too is part of man's state of wretchedness, for 'law is the power of sin'. Since Paul is talking about death and sin in general terms, as universal powers, albeit in a Jewish-Christian context, we may argue that Paul uses the word 'law' (vó $\mu$ s), too, as a general term and not as referring specifically to the Jewish law (Torah). ${ }^{29}$ In the context of 1 Cor 15 the issue of the Jewish law, or Judaism in general, is not at stake at all. 'The law' in verse 56, or rather: law, that is, all laws, including the Jewish law, is looked upon as the power of $\sin$. The parallelism between verse $56 \mathrm{a}$ and

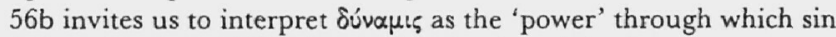
is brought about. ${ }^{30}$ The law is the stimulus of sin; it empawers men to sin. That is the meaning of verse 56b. In Paul's opinion, sin, being the sting of death, is incited by the law.

The connection between sin and law seems at first sight not very understandable, especially in the context of 1 Cor 15:54-57 and

${ }^{29}$ From a thorough analysis of the different components of meaning in vónoc as used by Paul, M. Winger comes to the conclusion that in Paul's undisputed letters '.. vónos most often refers definitely to Jewish vónos', but not always: '.. despite the preponderance of references to Jewish vópos, Paul understands and uses the term vónos in a broader sense, to refer to things other than Jewish vónos' (Law, 86). According to Winger there are, for instance, two references to vópos generically, viz. Rom $4: 15 b$ and $5: 13 b$ (Law, 83-84), verses that reflect a similar argumentation to that in 1 Cor 15:56. However, with regard to the latter passage, he remarks that he cannot see anything 'that is useful for establishing its meaning' (Law, $36 \mathrm{n} .87$ ). Nevertheless, Winger finds in 1 Corinthians at least one passage where vópas does not exclusively refer to Jewish law. He correctly interprets o vónos in 1 Cor 9:8 as referring to 'a larger class of vópol', of which the 'law of Moses' in 9:9 is a 'member' (Law, 71).

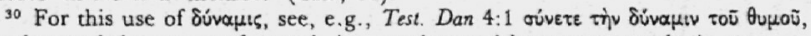
'understand the power of anger', i.e., understand how anger works in man. 
without Paul's letters to the Galatians and the Romans. Yet Paul's little aside about sin and law can be compared with certain views expressed by a number of popular Hellenistic philosophers. These philosophers too regard law(s) as part of the deplorable state of humanity, i.e. of its wretchedness and wickedness ( $x \alpha x i \alpha)$, or to use a more Jewish-Christian word, $\sin (\alpha \mu \alpha \rho \tau i \alpha)$. Especially among the Cynics we find a sharp criticism of the laws as part of their attack on man's disturbed sense of morality. In their criticism we can discern two concepts about laws and their place in life, which are found in many layers of classical and Hellenistic philosophy. The first concept $(\mathrm{A})$ is the antithesis of qúrs versus vónos; the second concept (B), which is closely related to the physis-nomos antithesis, is that of the 'origin and degeneration' (Ursprung und Entartung) of human culture. We will first examine these two concepts and then turn to some hard core Cynic criticisms on laws.

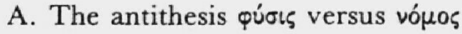

The antithesis of physis versus nomos (nature vs. law) originated among the Sophists in the fifth century B.C.E. ${ }^{31}$ Before the antithesis came into being the words physis and nomos were used in a complementary manner. The law was seen as a god-given way to establish an order in agreement with the natural order of the

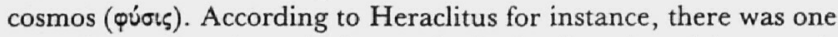
eternal cosmic order, which was the basis of truth and in accord-

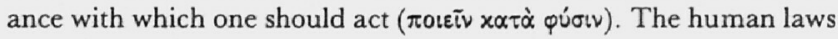
were in accordance with this god-given order ${ }^{32}$ The antithesis arose partially as a result of the troubled circumstances at the end of the fifth century which led to a questioning of the validity of the moral canons. ${ }^{33}$ The Sophists focused their attention on human

31 The first occurrence of the antithesis is found in Hippocrates ( 5 th- 4 th century B.C.E.), who applied it to describe the differences between cultures in his $\Pi_{\varepsilon p i}$

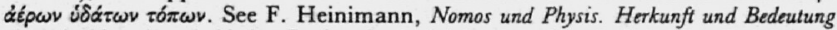
einer Antithese im griechischen Denken des 5. Jahrhunderts (Basel: Friedrich Reinhardt, 1945); M. Pohlenz, 'Nomos und Physis', Hermes 81 (1953) 418-38 (also in his Kleine Schriften [Hildesheim: Georg Olms, 1965], II, 341-60); for a brief introduction to this topic see also W.K.C. Guthrie, The Sophists (Cambridge: University Press, 1971) 55-134; S.-R. Nam, Das Problem 'Physis'- 'Nomos' im griechischen Denken im Verhältnis zur chinesischen Philosophie (Diss. Heidelberg, 1985) 7-90, and S. Vollenweider, Freiheit, 87-96.

${ }^{32}$ Heraclitus, frgs. 112, 114 (H. Diels-W. Kranz, Die Fragmente der Vorsokratiker [6th ed.; Berlin: Weidmann, 1951] I, 176).

33 W.K.C. Guthrie, Sophists, 94; S.-R. Nam, 'Physis'-'Nomos', 43. 
matters like ethics and politics rather than on nature. Protagoras' principle that man is the measure of all things, ${ }^{34}$ was also applied to the laws, which resulted in the opinion that laws were not godgiven, but man-made. Laws were regarded as the products of common human opinion, passed in order to regulate society, whereas physis was seen as the underlying eternal truth on which the laws should be based.

Fully developed and applied as a critique on human laws and conventions the antithesis is found in Hippias and Antiphon. ${ }^{35}$ In Plato's Protagoras Hippias addresses his fellow-debaters as follows: 'I regard you all as kinsmen and intimates and fellow-citizens by nature, not by law: for like is akin to like by nature, whereas law, despot (túpavvos) of mankind, often constrains us against nature'. ${ }^{36}$ Nature and law are directly opposed to each other: law, being the product of human opinion and convention, prevents man from

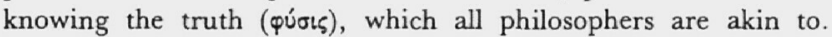
Xenophon, too, records Hippias' critical attitude towards the law. In discussion with Hippias, Socrates holds the opinion that 'he who

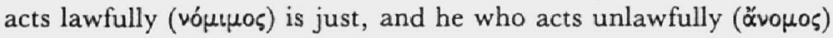
is unjust'. But Hippias objects, 'laws can hardly be thought of much account, Socrates, or observance of them, seeing that the very men who passed them often reject and amend them'. ${ }^{37}$ Hippias' point is that righteousness is not found in the laws because they are mere human convention. Only nature (qúos), also called the law of nature, is the basis of real righteousness.

Antiphon, a contemporary of Hippias, ${ }^{38}$ voices the same opinion as Hippias: 'those [regulations] of the laws are adventitious, those of nature necessary' (frg. $44 \mathrm{~A}$, col. 1). Even more, 'most of what is righteous according to law is hostile to nature' ( $\tau \dot{\alpha} \pi 0 \lambda \lambda \lambda \dot{\alpha} \tau \bar{\omega} \nu x \alpha \tau \dot{\alpha}$

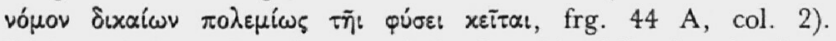
Righteousness and truth can only be found by following the 'laws of nature' (frg. $44 \mathrm{~A}$, col. 1). Human laws are insufficient for they

34 Plato, Theaetetus 152 A; Sextus Empiricus, Pyrrhoniae institutiones I, 216.

35 The nature-law antithesis is not exclusively used to criticize laws, but also vice versa, to criticize nature. In the latter case, nature is seen as a savage state of being (not divinely ordained) and law as the regulating order of cultivation. See W.K.C. Guthrie, Sophists, 60-84.

${ }^{36}$ Protagaras 337 C-D (trans. W.R.M. Lamb in LCL).

37 Memorabilia IV, iv, 13-14 (trans. E.C. Marchant in LCL).

38 Antiphon (480-411 B.C.E.) is known to us through various fragments to be found in H. Diels-W. Kranz, Vorsokratiker, II, 337-70. 
cannot prevent unrighteous deeds nor take away the suffering of victims; the law lets it all happen. And when it comes to a trial it appears that the law favours the guilty as much as the innocent (frg. 44 A, col. 6).

The Sophists' criticism of human laws was inspired by their search for eternal and universal righteousness and truth. Laws did not belong to the eternal order of nature; however, that did not mean that all laws were useless. Laws did establish a certain order, yet an order based on fear. Critias, another Sophist, writes that laws were instituted by people in order to chastise, and because people then transgressed the laws secretly the people invented gods who were said to see even the hidden trespasses of the law. ${ }^{39}$ The order established by the law has its ground in fear and not in righteousness or truth. Only by relating the laws to qúrıs could real righteousness be established. So on the one hand laws were seen as necessary because of the wickedness of mankind, but on the other hand the Sophists realized that laws themselves could not establish any righteousness. ${ }^{40}$ Furthermore, laws were an obstacle to real righteousness. ${ }^{41}$

After the fifth century B.C.E. the nature-law antithesis was adopted in various ways by numerous philosophers. Especially the Cynics picked up the antithesis ${ }^{42}$ and applied it rigorously to their ideas on ethics. Diogenes Laertius says about Diogenes of Sinope (404-323 B.C.E.), who may be considered the first real Cynic, that 'he did not give such authority to the things according to law ( $x \alpha=\dot{\alpha}$

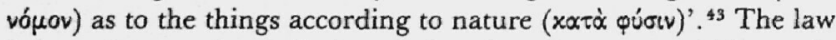
belonged to a city ( $\pi o^{\prime} \lambda_{\iota}$ ) and therefore it was something only cultural (גoreiov) ${ }^{44}$ which meant that more obedience had to be given to nature than to laws. In practice this meant that the Cynics

${ }^{39}$ Critias (460-403 B.C.E.), frg. 25, H. Diels-W. Kranz, Vorsokratiker, II, 386-8.

to A. Bill, La Morale et la Loi. Étude préliminaire sur le prablème de la loi dans la philosophie antigue préchrétienne (Strasbourg: Alsacienne, 1928) 54.

${ }^{41} \mathrm{Cf}$. also the saying attributed to Democritus in Epiphanius, Adversus haereses III, 2, 9, 'Laws are a bad invention, and it befits the wise not to obey the laws, but to live freely' (H. Diels-W. Kranz, Vorsakratiker, II, 129).

42 D.B. Dudley, $A$ History of Cynicism, From Diogenes to the 6th Century A.D. (London: Methuen, 1937) 14, 31; A. Bill, La Morale, 159.

${ }^{43}$ Diogenes Laertius VI, 71 (trans. R.D. Hicks in LCL). This attitude is also

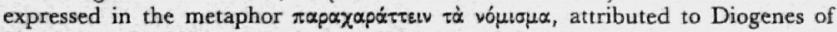
Sinope (see H. Niehues-Pröbsting, Kynismus, 43-77).

4t Diogenes Laertius VI, 72; cf. D.B. Dudley, Cynicism, 35-36. 
did not feel obliged to obey the laws of any city. They considered

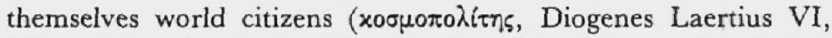
63 ), and thus they had to follow the law of the universe, i.e. the law of nature. ${ }^{45}$

The rejection of human laws remained part of the Cynic philosophy through the ages. The Cynics were notorious in this respect. According to Strabo, Mandanis, a pupil of Diogenes, said that the Greeks were wrong in one respect, 'they preferred law to nature'. ${ }^{45}$ Maximus of Tyre, who sympathized greatly with Cynicism, discusses in his 36 th discourse the question of to what extent Cynicism and Stoicism agree. He writes about Diogenes of Sinope that he 'went about the earth entirely free, ... not constrained by any law'. ${ }^{47}$ Maximus concludes that Diogenes was more free than Socrates, for Socrates obeyed human laws, the laws of Solon, which led to his death, whereas he should have obeyed the law of Zeus, the godly law or the law of nature $(36,6)$. To follow the law of nature, which included a negation of existing laws, ${ }^{48}$ it was necessary to become free, independent. ${ }^{49}$ Like pleasures and desires, human laws were seen as unnecessary obstacles in the process of becoming a good, wise man.

Also according to other Hellenistic authors, laws were mere human convention, by definition associated with all the negative aspects of human life of which only nature could liberate. Dio Chrysostom's attitude towards the law, for instance, seems ambiguous. He is ambiguous because he is playing the sophistical game, taking more or less opposite views. ${ }^{50}$ On the one hand Dio glorifies the law, on the other hand he sharply criticizes it. His 75 th discourse (On law) is a eulogy on the law. The law is more serviceable to a city than a wall $(75,1)$, it is called 'king of men and gods' $(75,2)$. However, in his 76 th discourse (On custom) the law is contrasted with custom ( $(20 \circ)$, also called the 'unwritten law' (76,

45 H. Schulz-Falkenthal: 'Die Kyniker stellten sich außerhalb der Gesellschaft und lebten als Außenseiter nach "Naturgesetzen" die sie sich selber gaben'

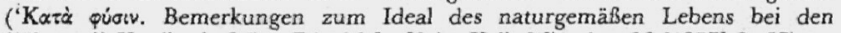
"älteren" Kyniker', Wiss. Zeit. M.L. Univ. Halle-Wittenberg 26 [1977] 2, 57).

46 Strabo, Geographia 15, 1, 65.

4 Maximus Tyrius, Dissertationes 36, 5 (trans. F. Sayre, Diogenes of Sinope. A Study of Greek Cynicism [Baltimore: J.H. Furst, 1938] 9).

${ }_{48}$ F. Sayre, Diogenes, 12.

49 Maximus Tyrius, Dissertationes 6, 5; Epictetus, Dissertationes IV, 1, 158; 7, 17.

50 Cf. A. Bill, La Morale, 194-6. 
$1)$, which is written within the hearts instead of on tablets of wood or stone $(76,3)$. The written law creates a 'polity of slaves', but the unwritten law a 'polity of free men' $(76,4)$. In his 80 th discourse, titled On freedom, he goes even further, stating that Solon, one of the earliest lawgivers (vopotétns), had framed such laws as he assumed the Greeks would accept, instead of making laws in accordance with the law of nature. 'He composed bad laws ... laws which would satisfy bad men' $(80,4)$. These laws suppress people and prevent people from being free; they are the bonds of slavery. Despite the positive function which Dio Chrysostom attributes to the law, he recognizes at the same time its negative side. The law itself does not provide any justice, nor any guidance for virtuous living. The law can chastise, but it cannot prevent people from doing evil. Therefore, in accordance with the Sophists, Dio maintains that the human laws should not be abandoned altogether, but should not be taken as a guiding principle either.

Whereas Dio Chrysostom identified nature with custom, or unwritten law, ${ }^{51}$ Epictetus the Stoic identified nature with the 'law of God' (Dissertationes I, 29, 13; 29, 4), also called the 'law of nature' (vópos фuø:xós, III, 17, 6). The laws of God should be valued more highly than human laws, or, as Epictetus calls them, 'the laws of Masurius and Cassius'52 (IV, 3, 12). Even more, the human laws are 'wretched' ( $\tau \alpha \lambda \alpha i \pi \omega \rho \circ)$ ), they are 'laws of the dead' (I, 13, 5). Instead, one must follow the laws of $\operatorname{God}(I, 13,5)$ which will lead to freedom. ${ }^{53}$

\section{B. The origin and degeneration of culture}

Widely current in the Hellenistic world was the idea that over the centuries humanity has declined since the glorious times of its beginning. The beginning of human culture was seen as a golden age; owing to man's wickedness, however, society slowly degenerated. According to many philosophers, the times had

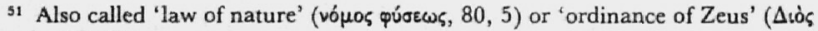
(equóv, 80, 6).

s2 Two distinguished jurists of the first half of the first century C.E.

53 Also Cicero speaks of a law of nature in contradistinction to written laws. Justice is more than 'conformity to written laws and national customs'; justice only exists by nature (De legibus II, xvii, 42), to which all laws and customs should be conformed (II, v, 13; xvi, 43). Only through the divine reason which is derived from nature one can distinguish between right and wrong. Therefore reason itself is a law (II, iv, 10). 
changed for the worse, and man's goal was to return to the wonderful time of his ancestors. This so-called idea of Ursprung und Entartung ${ }^{54}$ appears in many authors, Greek and Latin, and in different forms. ${ }^{55}$ They differed as to when and how the degeneration actually started and how man was able to regain the primeval bliss of the golden age.

Posidonius is one of the philosophers who developed this view of history ${ }^{56}$ with special attention to the position of the law(s). In his discussion of Judaism, ${ }^{57}$ for instance, he glorifies the beginning of the Hebrew people under the guidance of Moses, a good and pious leader who governed his people very well (Strabo, Geographia 16, 2, 36). Moses was a good leader because, being a priest, he received his ordinances directly from his God. However, after Moses 'superstitious' priests were appointed and 'tyrannical people'. These leaders ordered all kinds of strange observances like circumcisions, excisions, and abstinence of flesh $(16,2,37)$. Posidonius concludes, in the words of Strabo: 'their beginning was not bad,

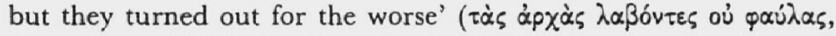

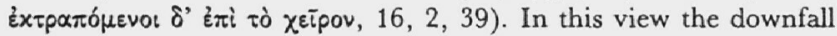
from the golden times was a twofold process: from piety to superstition and from righteousness to tyranny. ${ }^{58}$ The decadence of humanity also concerned the laws. Posidonius makes a distinction between the good and righteous laws (ordinances) of the golden age, those of Moses, and the tyrannical laws passed in the time after Moses.

For Posidonius the earliest laws, composed by the ancient lawgivers like Moses and Solon, belong to the golden age. Yet not all authors who have written on the concept of the origin and

54 The phrase is taken from K. Reinhardt, Poseidonios über Ursprung und Entartung (Heidelberg: Carl Winter, 1928).

55 A.O. Lovejoy-G. Boas, Primitivism and Related Ideas in Antiquity (Baltimore: John Hopkins, 1935) 23-53; E.R. Dodds, 'The Ancient Concept of Progress', The Ancient Concept of Progress and other Essays on Greek Literature and Belief (Oxford: Clarendon, 1973) 13.

56 The works of Posidonius (c. 135-51 B.C.E.) are all lost; we only have fragments and excerpts of them in the works of Diodorus Siculus, Strabo, and Athenaeus. See for a detailed analysis of the problem of reconstructing Posidonius' works, J. Malitz, Die Historien des Poseidonios (Zetemata 79; München: Oscar Beck, 1983) 34-59.

57 Strabo, Geographia 16, 2, 34-40.

s8 See particularly 16, 2, 37; furthermore, K. Reinhardt, Ursprung und Entartung, 22; M. Whittaker, Jews and Christians: Graeco-Roman Views (Cambridge: University Press, 1984) 50-52. 
degeneration of culture agree on this point. Seneca, for instance, sees the degeneration start before the time of the (first) laws and regarded the laws as a reaction to the degeneration of mankind. ${ }^{59}$ Laws were made to control the wickedness of men and thus they are not bad in themselves. Philo agrees with Seneca on this point. According to Philo the degeneration started before the time of the law, already with Adam, and the law itself (the law of Moses) was made to control and order the disordered and sinful society. ${ }^{60}$

The Cynics, who of all philosophers held the strongest views about the degeneration of mankind, ${ }^{61}$ went even further: because laws were the result of men's wickedness, the laws themselves were not good either. Men should return to the time when there were no laws, the golden time of their ancestors when people lived according

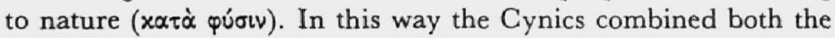
antithesis of nature vs. law and the concept of the degeneration of humanity into one sharp criticism of human culture and into a plea to return to a life in accordance with nature.

\section{Cynics and their valuation of laws}

The Cynics considered themselves to be 'called to the healing of a sick culture'. ${ }^{62}$ Therefore they criticized and rejected all human convention and lived what they considered to be a life in harmony

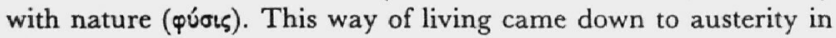
morals, self-sufficiency, and independence. ${ }^{63}$ Human laws and con-

59 Seneca, Ad Lucilium Epistulae Morales 90, 4-6; cf. also Tacitus, Annales III, 26.

60 In Philo's view the law of Moses is in agreement with the law of nature and the ordinances of Moses are 'nothing else than memorials of the life of the ancients' (De Abrahamo 5). In general, laws are meant to fill 'the souls of free men with comfortable hopes; but he who gains this virtue of hopefullness without being led to it by exhortation or command has been educated into it by a law which nature has laid down, a law unwritten yet intuitively learnt' (De Abrahamo 16; trans. F.H. Colson in LCL). See for Philo's concepts of unwritten law and law of nature, R.A. Horsley, 'The Law of Nature in Philo and Cicero', HThR 91 (1978) 35-59; J.W. Martens, 'Unwritten Law in Philo: A Response to Naomi G. Cohen', JJS 43 (1992) 38-45; for the concept of unwritten law in general see also, R. Hirzel, "Arpospos Nónos', Abhandlungen der phil.-hist. Classe der kön. Sächsischen Gesellschaft der Wissenschaften 20 (1903) 1-100. 13.

61 A.O. Lovejoy-G. Boas, Primitivism, 117-23; E.R. Dodds, Concept of Progress,

62 E.R. Dodds, Concept of Progress, 17; E. Zeller, Die Philosophie der Griechen in ihrer geschichtlichen Entwicklung (5th ed.; Leipzig: O.R. Reisland, 1922) II, 1, 332.

63 E. Zeller: 'Sittenstrenge, Bedürfnislosigkeit, Unabhängigkeit' (Philosophie, II, 1,

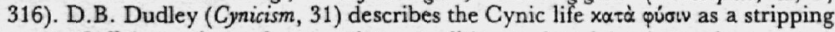
away of all 'accretions of conventions, tradition and social existence'. 
vention were seen as bonds which hindered their freedom, a freedom which was present in the golden age. ${ }^{64}$

The Cynic criticism of human conventions and laws is recorded by Plutarch who writes about Anacharsis ${ }^{65}$ that he laughed at Solon 'for thinking that he could check the injustice and rapacity of the citizens by written laws'. Laws are just like spiders' webs, they hold the weak, but will be torn by the rich and the powerful. ${ }^{66}$ Solon replies that he had made the laws 'in such a manner that the practice of justice was more advantageous than the transgression of laws' (V, 3). But, the author concludes, 'the results justified the conjecture of Anacharsis rather than the hopes of Solon' (V, 3). The laws were introduced because of man's wickedness, and were of no help in repelling this wickedness. Similarly, Plutarch comments on the laws of Lycurgus, that they were regarded as 'efficacious in producing valour, but defective in producing righteousness'. ${ }^{67}$

In a pseudepigraphic letter attributed to Heraclitus (Ep. 7), the Cynic criticism of society, and particularly its immorality, is the dominant theme. In the letter ${ }^{68}$ the author criticizes the Ephesians for their fraud, dishonesty, sexual aberration, lack of piety, and luxurious living. Their immorality is conspicuously apparent in the decree by which they banish Heraclitus from the city. The decree stipulates that everyone who does not laugh has to leave the city and Heraclitus is the only one who does not (want to) laugh because he rejects the immoral behaviour of the Ephesians. It is rather he, Heraclitus, who should be the judge of the Ephesians than vice versa. He concludes:

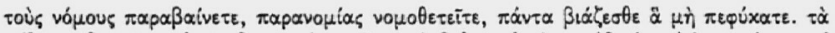

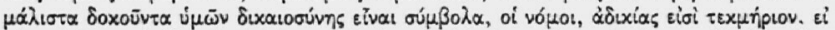

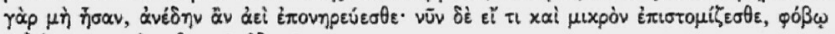

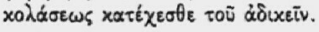

of See F.S. Jones, Freiheit, 93, and the references to primary sources and secondary literature mentioned there.

${ }^{65}$ Anacharsis, a 6th century B.C.E. sage, is often displayed with Cynic characteristics. See J.F. Kindstrand, Anacharsis. The Legend and the Apophthegmata (Uppsala: Almqvist and Wiksell, 1981).

66 Solon V, 2 (trans. B. Perrin in LCL). Cf. Diogenes Laertius I, 64-65, where Solon himself notices the same weakness of his laws: good leaders will benefit from his laws, tyrant leaders will not be restrained by them.

${ }^{67}$ Lycurgus 28 (trans. B. Perrin in LCL).

${ }_{68}$ The letter dates from the first century C.E.; see H.W. Attridge, First-century Cynicism in the Epistles of Heraclitus (HTS 29; Missoula: Scholars, 1976) 6. 
You transgress the laws; you enact illegalities; you perform by force everything which you cannot do by nature. The things which seem to be preeminently the symbols of justice among you, the laws, are evidence of vice. For if they did not exist, you would commit vice freely all the time, but now you are curbed, even if just a little; by fear of punishment you are kept from committing injustice. ${ }^{69}$

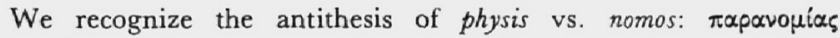

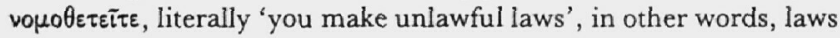
against the law of nature. ${ }^{70}$ Furthermore, the laws bring to light man's wickedness, they are evidence of vice. Nevertheless, they do impose some order on society, for if they were absent man would commit vice unceasingly, but they only do so by inspiring fear of punishment. The laws do not teach any righteousness; at the most, they repel some wickedness.

A criticism similar to that of Heraclitus is found in a pseudepigraphic letter attributed to Diogenes of Sinope (Ep. 28). This letter, probably stemming from the period from the first century B.C.E. to the first century C.E., ${ }^{71}$ is a criticism of life in general as lived by the 'so-called Greeks'. The author criticizes their lust for war, their lack of reason, their educational system which lacks education in righteousness, their uninhibited lustful behaviour, in other words their 'un-natural' way of living. Implied is a criticism of the laws.

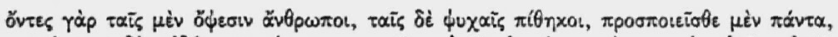

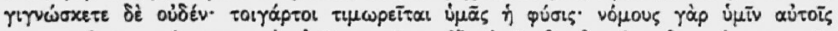

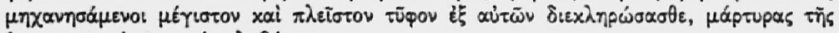

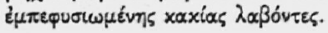

For although to all appearances you are men, you are apes at heart. You pretend to everything, but know nothing. Therefore, nature takes vengeance on you, for in contriving laws for yourselves you have allotted to yourselves the greatest and most pervasive delusion that issues from them, and you admit them as witnesses to your ingrained evil. ${ }^{72}$

The antithesis physis vs. nomos is brought to a climax: by making laws, men have created a delusion which will eventually come upon themselves. The laws do not provide order, but will turn against society, a vengeance of nature, according to the author. Further-

\footnotetext{
69 Text and translation taken from H.W. Attridge, Heraclitus, 74-75.

${ }^{70}$ For the expression 'law of nature' in the same epistle, see H.W. Attridge, Heraclitus, 72, 5; 74, 18.

"See the introduction to the collection of Diogenes' letters in A.J. Malherbe, The Cynic Epistles. A Study Edition (SBL Sources for Biblical Study 12; Missoula: Scholars, 1977) 14-21.

${ }_{22}$ Text (trans. B. Fiore) taken from A.J. Malherbe, The Cynic Epistles, 120-1.
} 
more, laws are evidence of men's inborn wickedness. Laws and wickedness are connected in a double way: laws are evidence of, and in the end, will produce wickedness.

The Cynic criticism of laws can be summarized in three points. First of all, laws do not belong to the realm of nature and are therefore by definition insufficient and unrighteous. Secondly, laws are composed because of the degeneration of humanity, they are the proof of man's wickedness. Thirdly, in the course of time laws are made by wicked people, a further result of the degeneration of humanity.

We can conclude that a relationship between laws and wickedness is often made in classical and Hellenistic philosophy, especially to describe the immorality of humanity. ${ }^{73}$ Against this criticism of laws and the negative view of humanity stands the belief in philosophy through which one can become truly moral and righteous. The wise do not need laws, because they will do good anyway. ${ }^{74}$ Demonax sums it all up when he says, 'that in all likelihood the laws were of no use, whether framed for the bad or the gaod; for the latter had no need of laws, and the former were not improved by them'. ${ }^{75}$

\section{1 Cor 15:56 and its context}

In his short aside on the role and power of death in human life in 1 Cor 15:56 Paul describes the miserable state of humanity with the help of Hellenistic ideas. The Hellenistic notion of the degeneration of humanity seems to have enabled Paul to connect death with $\sin$. With Philo he agrees that the degeneration of mankind, characterized by death and sin, started with the fall of

${ }_{73}$ Cf. Strabo who, supposedly refering to Res publica $404 \mathrm{E}$ - $405 \mathrm{~A}$, reports that Plato had said that 'where there are very many laws, there are also very many lawsuits and corrupt practices, just as where there are many physicians, there are also likely to be many diseases' (Geographia 6, 1, 8, trans. H.L. Jones in LCL).

${ }^{74}$ Diogenes Laertius V, 20, "When asked what the advantage he [Aristotle] had ever gained from philosophy, he replied, "This, that I do without being ordered what some are constrained to do by their fear of the law" " (Cicero, De re publica I, 3, says the same about Xenocrates; see also Diogenes Laertius II, 68-69; VI, 11).

75 Lucian, Demonax 59 (trans. A.M. Harmon in LCL). According to Lucian Demonax was a pupil of Demetrius and Epictetus (Demonax 3) who had Diogenes of Sinope and Socrates as his examples (Demonax 5). 
Adam. However, whereas for Philo the Jewish law is a way to overcome this fallen state, Paul rejects any law, subscribing to the negative view of law that was current among the Cynics who regarded laws as part of the degeneration of humanity. ${ }^{76}$ In Paul's opinion, death operates in the present age, and its 'sting', through which it brings mortality to all men, is sin. Law is the stimulus, the catalyst of men's wickedness.

Paul sympathized with this negative attitude towards law because it fitted quite well in his apocalyptic world-view. ${ }^{77}$ According to him, the present age was a time of evil but he was convinced that since the death and resurrection of Jesus Christ, the present order or aeon was running towards its end. Not only death and sin, but also law as part of human culture and convention, are characteristics of the old order and will pass away. At the end of time, when Christ returns, death will decisively be destroyed, which implies the end of the old order in all its aspects.

There is reason enough to believe that the Corinthians understood Paul's short digression on the deplorable state of mankind in 1 Cor 15:56 very well. From other data in 1 Corinthians we may conclude that the Christian community in Corinth was deeply influenced by a Graeco-Roman world-view. Their emphasis on wisdom, spiritual gifts, freedom, and the power to live as one wants to, together with a denial of the bodily resurrection of the dead, are clear proofs of their thoroughly Hellenistic way of thinking. They experienced the gifts of the Holy Spirit, they felt free, they even felt 'kings' (1 Cor 4:8). Through his letter Paul tried to correct this attitude. He pointed out to them where they were wrong. He drew their attention, for instance, to the virtue of love as a restriction of their ecstatic utterances and their freedom, but a necessity for the building up of the Christian community.

In his argumentation about the future resurrection of believers (1 Cor 15), Paul found it necessary to underline the power of death. He referred to the future eternal bliss to be received through resurrection at the end of time, but at the same time he emphasized the role of death in the present age. By connecting death with sin and

76 In Josephus, too, we find such a negative view of law in general; the Jewish Torah, however, is an exception: it is a code which by far surpasses all other laws (see Contra Apionem II, 145-295).

77 See also A.O. Lovejoy-G. Boas, Primitivism, 85. 
sin with law Paul described humanity with the help of concepts which he shared with many of his Hellenistic contemporaries and which we may suppose were well-known to his adressees in Corinth too.

Paul's understanding of the Jewish law in his polemics with Judaizing Christians in his letters to the Galatians and the Romans is shaped by this negative attitude towards law in general, as something belonging to the present aeon which will pass away at the end of time when death will decisively be destroyed. ${ }^{78}$

${ }^{78}$ Even in such a theological discussion on the law as Rom 7, Paul refers to law in a way that approximates this way of looking at it. It seems clear that in the discussions on law in Galatians and Romans also Greek philosophical elements are present. See also G. Bornkamm, 'Gesetz und Natur. Röm 2:14-16', Gesammelte Aufsätze (München: Kaiser, 1959) II, 93-118. 